Tjalling C. Koopmans Research Institute

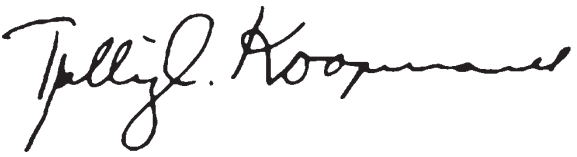

Discussion Paper Series nr: 09-13

\title{
Pension fund sophistication and investment policy
}

Jan de Dreu

Jacob A. Bikker 


\section{Tjalling C. Koopmans Research Institute Utrecht School of Economics Utrecht University}

Janskerkhof 12

3512 BL Utrecht

The Netherlands

telephone $\quad+31302539800$

fax $\quad+31302537373$

website www.uu.nl/NL/faculteiten/rebo/organisatie/depa rtementen/departementeconomie/onderzoek/pa ges/default.aspx

The Tjalling C. Koopmans Institute is the research institute and research school of Utrecht School of Economics.

It was founded in 2003, and named after Professor Tjalling C. Koopmans, Dutch-born Nobel Prize laureate in economics of 1975.

In the discussion papers series the Koopmans Institute publishes results of ongoing research for early dissemination of research results, and to enhance discussion with colleagues.

Please send any comments and suggestions on the Koopmans institute, or this series to J.M.vanDort@uu.nl

ontwerp voorblad: WRIK Utrecht

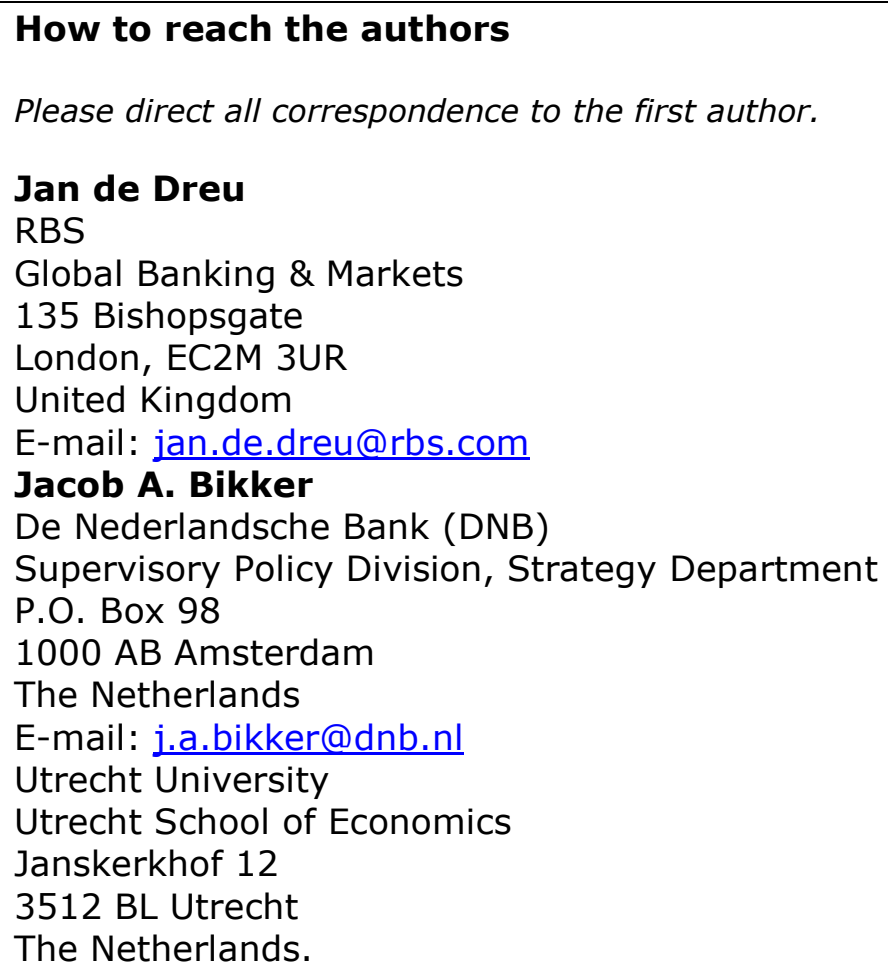


Utrecht School of Economics

Tjalling C. Koopmans Research Institute

Discussion Paper Series 09-13

\title{
Pension fund sophistication and investment policy
}

\author{
Jan de Dreu \\ Jacob A.Bikker ${ }^{b}$ \\ ${ }^{a}$ Global Banking \& Markets \\ RBS \\ ${ }^{\text {bS }}$ upervisory Policy Division, Strategy Department \\ De Nederlandsche Bank (DNB) \\ Utrecht School of Economics \\ Utrecht University
}

May 2009

\begin{abstract}
This paper assesses the sophistication of pension funds' investment policies using data on 748 Dutch pension funds during the 1999-2006 period. We develop three indicators of sophistication: gross rounding of investment choices, investments in alternative sophisticated asset classes and 'home bias'. We find that pension funds' strategic portfolio choices are often based on coarse and possibly less sophisticated approaches. Most pension funds, particularly the medium-sized and smaller ones, round strategic asset allocations to the nearest multiple of $5 \%$, similar to age heaping in demographic and historical studies. Second, many pension funds invest little or nothing in alternative asset classes besides equities and bonds, resulting in limited asset diversification. Third, medium-sized and smaller pension funds favor regional investments and as such not fully employ the opportunities of international diversification. Finally, we show that pension funds using less sophisticated asset allocation rules tend to opt for investment strategies with a lower risk-return profile.
\end{abstract}

Keywords: Pension funds, investment policy, portfolio choice, gross rounding, heaping, diversification, home bias, alternative investments, behavioral finance.

JEL classification: G11, G23.

\section{Acknowledgements}

The authors are grateful to Dirk Broeders, Paul Cavelaars and participants in the DNB research seminar on February 19, 2008, and in the Western Economic Association International Pacific Rim Conference, 24-27 March 2009, Kyoto, for valuable comments and suggestions and to Jack Bekooij for his excellent support in constructing the dataset. The views expressed in this paper are personal and do not necessarily reflect those of RBS or DNB. 


\section{Introduction}

In the current financial crisis pension funds have sustained huge losses on the market value of their assets. The crisis has shown that pension funds are heavily exposed to fluctuations in asset prices, thereby illustrating the importance of pension fund investment policies. The crash in equity prices, coupled with a decline of the long-term interest rate used to discount liabilities, has slashed the funding ratio of Dutch pension funds, with only minor relief from higher bond prices. In 2008 alone the drop in market value was over $17 \%$ of total pension assets in the Netherlands. These losses have large consequences since the assets of Dutch pension funds exceed annual GDP. Most pension funds now face significant funding gaps and are forced to increase premiums, cut wage and price indexation and, if the funding ratio does not recover in time, they may have to cut pension rights. Evidently, the investment losses have profound implications and have raised questions as to the quality and sophistication of pension fund investment policies.

A major contribution in the finance literature on optimal asset allocation is the two-fund separation theorem, which prescribes investors to hold an optimal portfolio of risky assets in combination with the risk-free asset (Tobin, 1958). This optimal portfolio should be mean-variance efficient, implying that for a given expected return, no additional diversification can lower the portfolio's risk (Markowitz, 1952). These theorems are building blocks of CAPM, which states that there is only one optimally risky portfolio, that is, the market portfolio (Sharpe, 1964). If this is the correct model, asset allocations for investors with different risk appetites should be simply different linear combinations of the riskless asset and the market portfolio. This implies that investors, including pension funds, should keep the ratio of bonds to stocks and other asset classes unchanged across all portfolios and vary allocations to the risk free asset, reflecting varying risk appetites. The finding that investors hold different proportions of risky assets - including the ratio of bonds to stocks conflicts with the two-fund separation theorem and is called the Asset Allocation Puzzle (see also Canner et al., 1997). For pension funds the risk free portfolio would exactly replicate the pension liabilities and be made up of long-term inflation-linked bonds and common bonds. In practise, however, this portfolio is difficult to construct due to limited liquidity.

Whereas in many countries, pension funds play a central role in providing old age benefits, the economic literature has so far paid little attention to how well pension funds perform this task in reality. The asset allocation strategy of a pension fund is the main driver of the risks and returns of its pension plans. Asset allocation involves two decisions. First, the level of risk appetite must be determined in line with the preferences of pension scheme participants and sponsor companies. 
Second, the allocation of investments to different asset classes should be chosen in such a way that expected returns are maximized, given the pension fund's liabilities and its risk appetite. A welldeveloped asset allocation policy is critical to achieving this second task.

Most countries impose few regulatory constraints on the investments of pension funds, which thus enjoy considerable freedom in allocating their assets. The risk-return assumptions for the different asset classes and the joint utility function of participants and sponsors determine the optimal combination of asset classes. The optimal investment policies may follow from Monte Carlo simulations of asset-liability management (ALM) studies, given preferences (such as the risk-return trade off) and market return and volatility assumptions. This paper does not evaluate how well pension funds allocate their wealth to various asset classes (see e.g. Campbell and Viceira, 2002). Rather, we assess the level of sophistication of the pension funds' investment policies. We also examine how risk taking correlates with asset allocation policy.

This study investigates the investment policies of 748 Dutch pension funds during the 1999-2006 period. At the end of 2007, total pension fund assets in the Netherlands amounted to some $€ 719$ billion. ${ }^{1}$ As percentage of GDP at $127 \%$, the Dutch pension system ranks among the largest in the world. We find that the asset allocation policies of many funds appear to be relatively simple and that they vary widely, which raises the question whether all these policies can be optimal, given pension fund specific conditions and preferences. We develop three measures of being (less) sophisticated. The first yardstick assumes that less sophisticated pension funds are less knowledgeable about their (unknown) optimal asset allocation, or use more human judgment, and are therefore more likely to choose plausible numbers. They do not use detailed calculations, but have a systematic tendency to prefer 'attractive' numbers, for example by rounding of allocation shares to the nearest 5\%. This phenomenon is sometimes called heaping and is well-known in sociological and historical studies. Most pension funds, particularly the smaller ones, but many large funds as well, apply such a coarse approach in allocating wealth to asset classes. Our second measure investigates how much has been invested in more complicated alternative asset classes besides equities and bonds, thereby improving asset diversification. We find that smaller and less sophisticated pension funds tend to diversify less. Third, we study 'home bias' and find that many funds favor regional investments, thereby limiting international diversification. These findings indicate that the investment policies of most pension funds are likely less sophisticated. Though it

\footnotetext{
${ }^{1}$ For 2008 , first estimates for total assets are $€ 606$ billion, being 102\% of GDP.
} 
may be smart for a less sophisticated pension fund to avoid investments in more complicated alternative asset classes and in less-known countries.

We also find that less sophisticated pension funds invest less in risky assets and more in bonds. The lower risk appetite of small funds may point to an awareness of the limited sophistication of their risk management. Low risk appetite might then be a fourth indicator of limited sophistication. Conversely, large funds may suffer from overconfidence because they put too much trust in (selfdeveloped) theories and models. At least over the last few years, and probably over the last decade, investments in risky asset classes, such as equity and real estate, have been less rewarding than investment in bonds. For both theoretical and practical reasons, this paper does not consider risk appetite or returns on investment as indicators of sophistication. All in all, the results suggest that there is scope for improvement in the investment strategies of especially the smaller and mediumsized pension funds.

This paper is organized as follows. Section 2 presents literature on behavioral biases and imperfect asset allocation, while Section 3 describes the dataset used. Section 4 develops three measures of sophistication in pension funds' investment behavior, and examines their mutual connection and their relationship to the size of pension funds. Section 5 estimates a possible relationship between the measures of investment sophistication and risk taking. The last section concludes.

\section{Behavioral biases and imperfect asset allocation}

Private investors often use simple rules of thumb in allocating their wealth across asset classes, resulting in suboptimal investment portfolios. The behavioral finance literature classifies such suboptimal investment decisions as behavioral biases or cognitive errors. Individuals use heuristics, or rules of thumb, because they have limited attention, memory, education, and processing capabilities. A number of papers have shown that individual investors often rely on simple allocation rules. Findings in the behavioral finance literature include in fact that asset allocations tend to be either zero or 100 percent in equities (Agnew et al., 2003) and that investors use the $1 / \mathrm{n}$ rule to allocate their money among the $\mathrm{n}$ funds they invest in (Huberman and Jiang, 2006). Benartzi and Thaler (2001) show that some investors use the $1 / \mathrm{n}$ rule to allocate investments equally among funds offered in pension plans and, consequently, that the equity allocation of investors is influenced by the proportion of stock funds offered. The natural conclusion is that the use of heuristics can lead to suboptimal asset allocations for private investors. 
The tendency to round figures coarsely or to choose attractive numbers is also documented in a number of demographic and historical studies. For instance, self-reported age data in countries or time periods with low average levels of education often show high frequencies at attractive, 'round' numbers. This phenomenon is called age heaping. Individuals with limited knowledge about their age are found to have a higher propensity to choose a 'plausible' number. These individuals do not choose random numbers, but instead have a systematic tendency to choose attractive numbers, particularly those ending in 5 or 0 . This phenomenon is reported for a number of data sources, including census returns, tombstones, and tax data. Demographic studies have shown that age heaping is correlated to education (e.g. Bachi 1951), income (e.g. Myers, 1976), illiteracy (Budd and Guinnane, 1991) and, more generally, human capital (Baten, Crayen and Hearn, 2006).

While there is a growing literature documenting behavioral biases of private investors, much less is known about professional parties. Institutional investors are generally considered to be more sophisticated than private investors and are therefore assumed to invest more optimally. A number of theoretical papers argue that more sophisticated investors suffer less from cognitive biases or irrational behavior (e.g. Banerjee, 1992, DeLong et al., 1990, Hirshleifer et al., 1994, and Shleifer and Summers, 1990). However, there is little empirical evidence documenting (i) the investment behavior of institutional investors, or (ii) how this behavior is influenced by their level of sophistication.

To fill this gap in the literature, this paper studies the investment behavior of institutional investors possessing varying degrees of sophistication. Scale advantages should enable large investment funds to hire competent experts and consultants and spend significant time and resources on optimizing their investment policies. Hence, we hypothesize that large funds are more sophisticated investors able to select optimal investment policies. Consequently, large funds should have a lower propensity to use heuristics in determining their asset allocation, but instead should use more advanced rules to guide investment policy. Investors at higher levels of sophistication are also expected to be more knowledgeable about alternative asset classes and consequently to invest relatively more in them. These factors should enable institutional investment funds to apply better asset class allocation strategies than small funds. Ultimately, higher levels of sophistication should also lead to better asset-liability management policies, but testing this latter hypothesis is outside the scope of this paper. 
Similar to the behavioral finance literature on individual investors, we find that institutional investors are also susceptible to behavioral biases. At the same time, however, we find that the investment behavior of institutional investors is influenced by their level of sophistication. In particular, we show that smaller institutional investors more often use heuristics for their investment strategy, diversify their investments less and take less risk.

There are at least two reasons why the pension sector in the Netherlands provides an ideal setting to study the impact of investor sophistication on investment behavior. First, total assets under administration, our measure of the size of pension funds which may be an indicator of sophistication, varies widely. Pension funds ranges in size from small institutions - with assets of less than 100 million euros (28\% of institutions) - to very large institutions with assets of more than one hundred billion euros. The variation in terms of participants is also wide, from less than 100 participants (5\% of institutions) to more than a million participants. Large institutions include industry-wide pension funds such as ABP and PFZW, which are among the biggest pension funds in the world. Small institutions are mostly company funds that provide pensions for the employees of a single company. Second, the Nederlandsche Bank collects comprehensive data on the investment policies of these institutions, which allows us to study their asset allocation decisions.

\section{Data}

We use a detailed dataset with quarterly figures on 748 Dutch pension funds for 1999:I-2006:IV, representing around $90 \%$ of total investments by pension funds in the Netherlands. Our sample includes 631 company pension funds, 95 industry-wide pension funds, and 10 professional group pension funds. ${ }^{2}$ The data is from the Nederlandsche Bank, responsible for the prudential supervision of pension funds and their regulatory compliance. For each pension fund data is available on its strategic asset allocation, asset sales and purchases and on the market value of its investments in various asset classes. Pension funds generally do not fully and continuously rebalance their actual asset allocation to their strategic allocation policies (see Bikker, Broeders and De Dreu, 2009). As a result actual asset allocations reflect both active policy decisions of pension funds as well as (recent) asset returns on the portfolio holdings. We investigate strategic asset allocations, since these alone reflect active choices of pension funds.

\footnotetext{
${ }^{2}$ Company funds provide pension plans to the employees of their sponsor company. They are separate legal entities, but are run jointly by the sponsor company and employee representatives. Industry funds provide pension plans for employees working in an industry. Such pension plans are based on a collective labor agreement between an industry's companies and the labor unions, representing the employees in that industry.
} 
The sample is an unbalanced panel, as not all pension funds are included throughout the sample period, due to new entrants, mergers, terminations, and reporting failures. ${ }^{3}$ Pension funds with less than two years of data and observations with evident reporting errors have been excluded, resulting in 748 selected pension funds. Table 1 presents summary statistics. The size of pension funds in the sample ranges from small pension funds with total investments worth less than $€ 1$ million, to large pension funds such as ABP, the public servants pension fund, with total investments of over $€ 200$ billion. The average and median sizes of pension fund assets equal, respectively, $€ 799$ million and $€ 53$ million. To compare pension funds with different levels of sophistication we have defined three size classes: small (investments of $€ 0-100$ million), medium ( $€ 100-1000$ million) and large ( $>€ 1$ billion). Although large in number ( $70 \%$ of the institutions), small pension funds administer only $2 \%$ of total pension fund investments.

Table 1: Summary statistics for various pension fund sizes (1999:1 - 2006:IV)

\begin{tabular}{lrrrr}
\hline & Small funds & Medium-sized funds Large funds & All funds \\
\hline Average number of participants & 1,977 & 15,747 & 236,040 & 26,523 \\
Average investments (million euros) & 29 & 320 & 8,276 & 799 \\
Total number of participants (million euros) & 0.6 & 2.3 & 10.1 & 13.1 \\
Total investments (billion euros) & 10.5 & 53.1 & 396.9 & 459.4 \\
Number of pension funds & 524 & 177 & 47 & 748 \\
\hline
\end{tabular}

\section{Sophistication and investment policy}

In order to assess the sophistication regarding pension funds' investment policies, this section develops three measures of sophistication, based on the data discussed above: (i) the use of gross rounding, (ii) investments in other simple or sophisticated asset classes, and (iii) home bias.

\subsection{Gross rounding of asset allocations}

We first examine the asset allocation strategies or the investment policies of pension funds. The histograms in figure 1 show the strategic equity and bond allocations of Dutch pension funds. ${ }^{4}$ Two patterns are striking. First, most remarkably, the strategic allocations cluster around numbers that are multiples of 5\%. Table 2 shows that the frequencies of $5 \%$ multiples used for strategic equity

Finally, professional group funds offer pension schemes to groups such as general practitioners and public notaries.

${ }^{3}$ We also compared the results for a balanced sample comprising 381 pension funds that reported at least seven years of data. The results are similar to the tables that are presented, suggesting that the survivorship bias is not a significant issue. 
and bond allocations far outstrip those of other numbers. Apparently, pension funds have a strong preference to round their strategic equity and bond allocations to the nearest $5 \%$. The figures further suggest that coarse rounding to the nearest $10 \%$ is more frequent than rounding to $5 \%$. Apparently, sets of ten are even more attractive than sets of five. Just as has been observed for private investors, we also notice that some pension funds take extreme positions of $0 \%$ and $100 \%$ in equities or bonds. Second, the dispersion of strategic equity and bond allocation across pension funds is large. ${ }^{5}$ The figures show little or no convergence around a certain strategic asset allocation indicating that (beliefs about) optimal asset allocation levels vary widely across pension funds, perhaps (partly) due to diverging conditions such as risk aversion and ageing. It is hard to belief that unknown preferences, such as risk aversion, would be able to explain the widely varying strategic assets allocations.

Figure 1: Frequency distribution of strategic equity and bond allocations of 748 pension funds
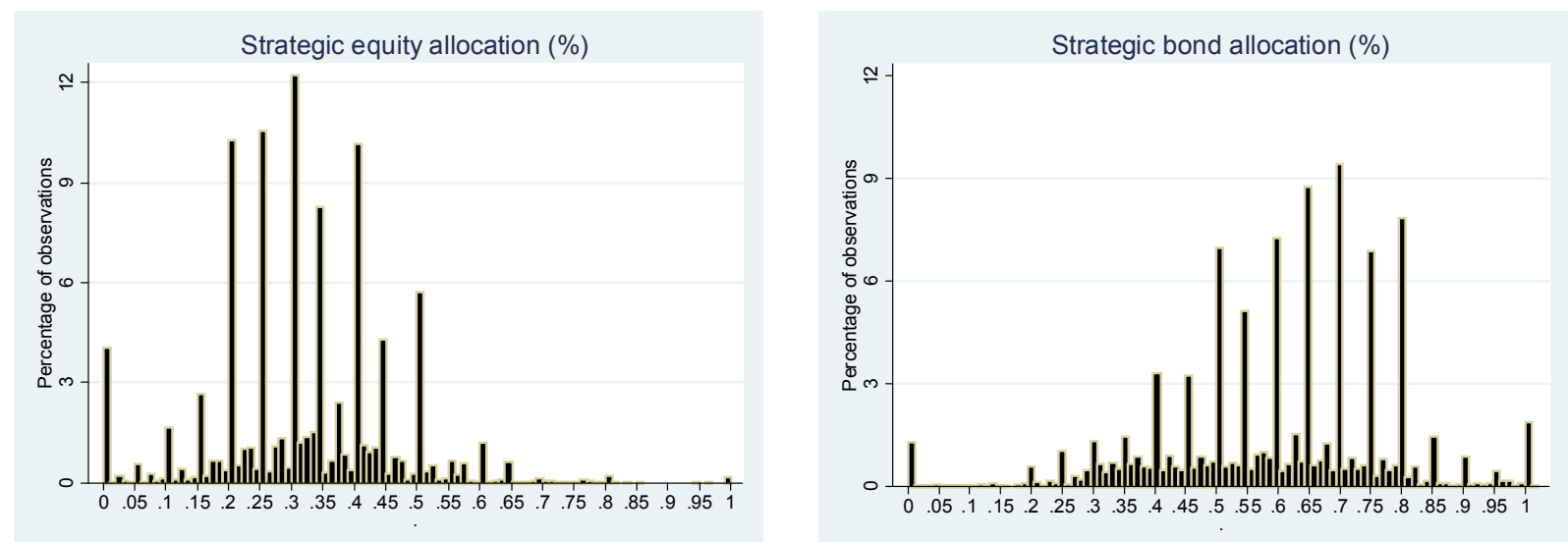

'Attractive numbers' for rounding should be simple to remember and easy to use for calculations. Multiples of $10 \%, 5 \%$ and also $2 \%$ exhibit those properties. The preference of pension funds to use 'attractive' numbers for their strategic asset allocation may be due to the absence of compelling arguments for more 'precise' figures on the allocation of wealth across asset classes. Table 2 shows the percentages of pension funds that use these attractive numbers for their strategic equity and bond allocation. Pension funds that use multiples of $10 \%, 5 \%$ or $2 \%$ for their strategic equity allocation as well as their strategic bond allocation are classified as 'using attractive numbers'. As

\footnotetext{
${ }^{4}$ Here, we disregard other asset categories, which represent relative small shares in total assets. For a number of (smaller) pension funds these shares are even zero, see Table 3. This is investigated further in Section 4.2.

${ }^{5}$ This is also clear from the histograms of actual equity and bond ratios, not shown here. These figures show smooth distributions (actual allocations are influenced by market movement and hence not rounded), but with the same wide dispersion.
} 
already suggested by Figure 1, multiples of 5\% (including tens) occur most frequently. ${ }^{6}$ On average, $60 \%$ of pension funds use multiples of $5 \%$ for their strategic equity and bond allocation, far above $20 \%$, the expected level in a uniform distribution of integers between $0 \%$ and $100 \%$. In fact, pension funds can (and some do) report their asset allocations in decimals. We only consider integers to calculate the uniform distribution, while we only consider multiples of $10.0 \%, 5.0 \%$ and/or $2.0 \%$ to be attractive numbers. So in reality, the expected use of attractive numbers would be even lower than assumed here.

Multiples of $10 \%$ are reported at slightly more than half the frequency for multiples of $5 \%$ indicating that on average pension funds slightly prefer even over odd numbers. The difference between multiples of $10 \%$ and multiples of $2 \%$ is only marginal indicating that percentages ending in 2, 4, 6 and 8 are little used. Table 2 shows also that small pension funds use attractive numbers significantly more frequently than medium-sized pension funds, while large pension funds use attractive numbers least frequently.

Table 2: Attractive numbers used for strategic equity and bond allocation (in \%)

\begin{tabular}{|c|c|c|c|c|c|}
\hline Attractive numbers & $\begin{array}{c}\text { Uniform } \\
\text { distribution }\end{array}$ & Small funds & $\begin{array}{l}\text { Medium-sized } \\
\text { funds }\end{array}$ & $\begin{array}{l}\text { Large } \\
\text { funds }\end{array}$ & All funds \\
\hline Multiples of $10 \%$ & 1 & 37 & 28 & 11 & 32 \\
\hline Multiples of $5 \%$ & 4 & 66 & 56 & 29 & 60 \\
\hline Multiples of $2 \%$ & 25 & 41 & 33 & 19 & 37 \\
\hline Multiples of $2 \%$ or $5 \%{ }^{a}$ & 36 & 72 & 63 & 41 & 67 \\
\hline
\end{tabular}

Explanation: Based on Chi-squared tests, all statistics are significantly larger (at virtually any significance level) than expected under a uniform distribution of integers between $0 \%$ and $100 \%$ (except the use of even numbers for large funds). Based on t-tests, the differences between attractive numbers used across different fund sizes are always significant at the $1 \%$ level. The uniform distribution used for Chi-squared and t-tests are based on the assumption that pension funds round their asset allocation to integers.

${ }^{a}$ Due to our definition of 'using attractive numbers' this row is by approximation equal to the sum of the two preceding rows minus the first row (which is the overlapping of the other two). Actually, this row is slightly higher because the respective definition is broader, e.g. covering allocation shares of $4 \%$ and $5 \%$.

Table 3 shows the combinations of equity and bond allocations for pension funds that round their strategic allocations for both asset classes to multiples of 5\%. In line with Figure 1, the table confirms that there is a large variation of investment policies with little convergence to a certain average or median strategy. The most common strategic allocations are between $20 \%$ and $50 \%$ for equities and between $50 \%$ and $80 \%$ for bonds (see shaded cells).

\footnotetext{
${ }^{6}$ Taking into account that in an interval from $0-100$ multiples of $5 \%$ occur twice as often, multiples of $10 \%$ are used relatively more frequently than multiples of $5 \%$, though the (relatively) difference is only small.
} 
The hypothesized optimal asset allocation of pension funds depends on risk preferences of participants and sponsor(s), their assessment of risks and returns of the different asset classes, macro-economic variables, such as wage growth, inflation and real interest rates, their funding ratio and the age structure of participants. Typically, asset-liability management (ALM) studies take these factors into account. These studies could be used to obtain suppose optimal asset allocation numbers, using Monte Carlo simulations based on preferences (such as the risk-return trade off) and on market return and volatility assumptions. However, in practice, ALM studies are not used directly to determine optimal portfolio investments across asset classes. Rather, they provide input into a human appraisal process. The widespread use of multiples of $5 \%$ indicates that the determination of strategic asset allocations could be developed further for the majority of pension funds.

Table 3: Frequency distribution of multiples of $5 \%$ used for strategic equity and bond allocations (in \% of observations)

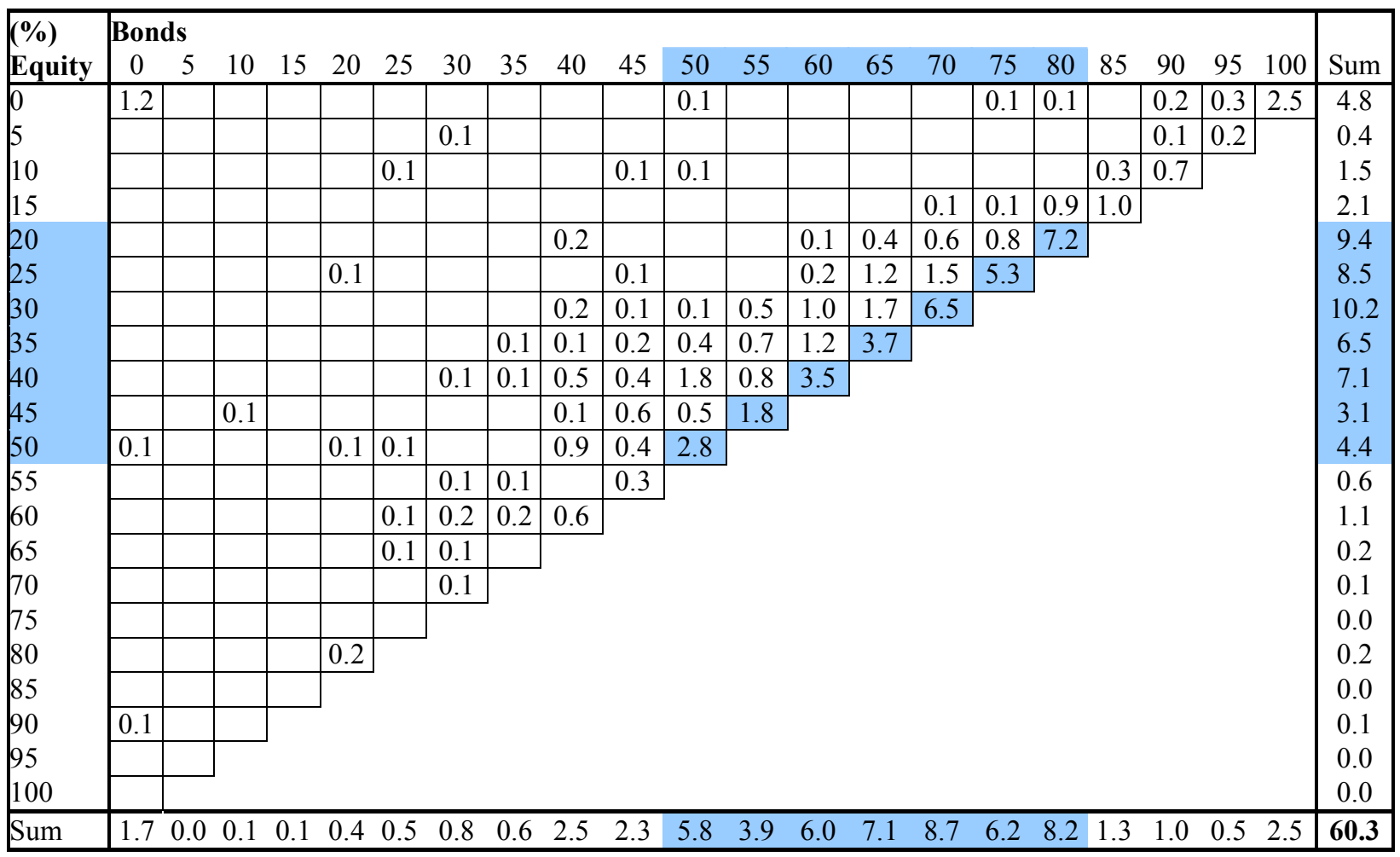

Explanation: Cells in the upper triangular with values below 0.05 are shown as blanks. The blue shading indicates the most frequently chosen combinations.

Table 4 presents the use of attractive strategic asset allocations by small, medium-sized and large pension funds over time. The statistics confirm that small funds are more likely than large funds to choose multiples of $5 \%$ for their investment strategies. On average, $66 \%$ of small pension funds 
choose a multiple of $5 \%$ for their strategic equity and bond allocations compared to only $56 \%$ of medium sized funds and $29 \%$ of large funds. There is some variation over time: the use of multiples of 5\% increases until 2002 (for large funds: 2003) and decreases afterwards. This may indicate that the use of ALM models in determining the strategic allocation has increased since 2002/2003. However, the finding that the use of multiples of 5\% is inversely related to size is consistent over the years. Differences in the use of multiples of $5 \%$ between small, medium-sized and large pension funds are significant at the $1 \%$ level for each year. These findings indicate that small pension funds use less sophisticated rules for their strategic asset allocation more often than large funds.

Table 4: Multiples of 5\% used for strategic asset allocation over time (1999-2006; in \%)

\begin{tabular}{lrrrr}
\hline Year & $\begin{array}{r}\text { Small } \\
\text { funds }^{\text {a }}\end{array}$ & $\begin{array}{r}\text { Medium- } \\
\text { sized funds }\end{array}$ & $\begin{array}{r}\text { Large } \\
\text { funds }\end{array}$ & All funds \\
\hline 1999 & 60 & 48 & 22 & 54 \\
2000 & 64 & 51 & 25 & 57 \\
2001 & 66 & 57 & 26 & 61 \\
2002 & 70 & 64 & 29 & 65 \\
2003 & 70 & 60 & 32 & 64 \\
2004 & 70 & 61 & 30 & 64 \\
2005 & 66 & 57 & 31 & 59 \\
2006 & 65 & 52 & 32 & 56 \\
Unweighed average & 66 & 56 & 29 & 60 \\
\hline
\end{tabular}

Explanation: For each year, the differences between frequencies for different fund sizes are significant at the $1 \%$ level (tested using t-tests). ${ }^{\mathbf{a}}$ Based on total investments, see Table 5.

Many pension funds, particularly small ones, use specialist external consultants to advise on their investment strategies and asset liability management. Because the number of specialist consultants with expertise on pension fund investment strategies is limited, such consultants often advise multiple pension funds. The recommended investment strategies are tailored to the preferences of participants and sponsors and the structure of assets and liabilities. However, if external consultants turned out to have a preference for recommending grossly rounded numbers to serve their clients, they would thereby contribute to the prevalence of attractive numbers in the asset allocation of pension funds. 


\subsection{Allocation across asset classes}

This section investigates how pension funds allocate investments across different asset classes. Our dataset distinguishes the following asset classes: equities, bonds, real estate, mortgages and loans, commodities, mixed mutual funds, money market instruments and other investments. More than $50 \%$ of pension funds base their strategic asset allocation on bonds and equities only and do not consider alternative asset classes such as real estate or commodities. This suggests that these funds ignore other, generally more sophisticated, investment opportunities, thereby limiting their scope for higher expected returns and/or further risk diversification.

Table 5 presents the allocation of pension funds' wealth across asset classes for funds of various size categories. It shows that larger pension funds allocate greater shares of their investments to equities and smaller shares to bonds, compared to smaller funds. Medium-sized funds take an intermediate position. Larger pension funds, seeking better diversification of risks, invest more in alternative assets than small and medium size funds. We split alternative investments into simple assets (money market funds and mixed mutual funds) and sophisticated assets (real estate, commodities and loans) Larger pension funds invest also significantly more in alternative sophisticated assets, and less in alternative simple assets, compared to small funds. This behavior is probably steered in part by supervisory regulations which require a more sophisticated risk management for institutions which invest in more risky alternative investments.

Table 5: Average strategic asset allocation by size classes (2006:IV)

\begin{tabular}{|c|c|c|c|c|c|c|c|}
\hline \multirow{2}{*}{\multicolumn{2}{|c|}{ Size classes pension funds ${ }^{a}$}} & \multirow{2}{*}{$\frac{\text { Equities }}{\operatorname{In} \%}$} & \multirow[t]{2}{*}{ Bonds } & \multirow[t]{2}{*}{$\begin{array}{l}\text { Alternative } \\
\text { investments - } \\
\text { simple }^{\mathrm{b}} \\
\end{array}$} & \multirow[t]{2}{*}{$\begin{array}{l}\text { Alternative } \\
\text { investments - }^{\text {sophisticated }} \\
\text { soph }^{\mathrm{c}}\end{array}$} & \multicolumn{2}{|r|}{$\begin{array}{l}\text { Average } \\
\text { investments } \\
\text { (mln euro) }\end{array}$} \\
\hline & & & & & & & \\
\hline $0-100$ & (small) & 28 & & 63 & 5 & 4 & 37 \\
\hline $100-1,000$ & (medium sized) & 35 & & 58 & 1 & 6 & 332 \\
\hline$>1,000$ & (large) & 39 & & 47 & 2 & 12 & 9,520 \\
\hline \multicolumn{8}{|c|}{ Use of 'attractive numbers' for asset allocation } \\
\hline Funds that & und to $5 \%$ & 30 & & 61 & 4 & 4 & 383 \\
\hline Funds that & o not round to $5 \%$ & 35 & & 56 & 2 & 8 & 2,475 \\
\hline
\end{tabular}

Explanation: All statistics are simple averages in percentages. Differences between small, medium-sized and large funds for all asset categories distinguished are significant at a significance level of $1 \%$, except for simple alternative investments between medium-sized and large funds.

${ }^{a}$ Based on total investments (million euro). ${ }^{\text {b }}$ Simple alternative investments include money market funds and mutual funds. ${ }^{\mathrm{c}}$ Sophisticated alternative investments include real estate, commodities and loans.

The lower panel of Table 5 reveals evidence that pension funds which round their strategic asset allocation to 5\% multiples hold more bonds and simple alternative assets whereas funds that do not 
round invest more in equity and sophisticated alternative assets. This reveals that the two measures of sophistication, heaping and alternative asset investments, are correlated.

Table 6 gives further insight in the relationship between investments in sophisticated alternative assets and pension fund sizes. The table shows that the majority of small funds invest less than $10 \%$ of their assets in sophisticated assets, whereas only $31 \%$ of the large funds have less than $10 \%$ invested in 'alternative assets'. Only $15 \%$ of small funds invest more than $10 \%$ in sophisticated assets whereas $69 \%$ of the large funds do so. The lower panel of this table shows that funds that round to $5 \%$ multiples invest significantly less in sophisticated alternative assets. The outcomes of Table 6 confirm the finding that large funds better diversify their investments and choose a higher risk-return profile. Furthermore, this attitude turns out to be inversely correlated with heaping.

Table 6: Investments in sophisticated assets ${ }^{\mathrm{a}}$ by size and sophistication of pension funds (in \% of all pension funds; 2006:IV)

\begin{tabular}{lccccc}
\hline & \multicolumn{5}{l}{ Investments in sophisticated assets } \\
\cline { 3 - 6 } Size classes & pension funds ${ }^{b}$ & $0 \%$ & $0-10 \%$ & $10-20 \%$ & $>20 \%$ \\
\hline $0-100$ & (small) & 56 & 29 & 10 & 5 \\
$100-1,000$ & (medium sized) & 40 & 32 & 22 & 6 \\
$>1,000$ & (large) & 9 & 22 & 57 & 12 \\
Use of 'attractive numbers' for & asset allocation & & \\
\hline Funds that round to 5\% & 63 & 17 & 15 & 5 \\
\hline \multicolumn{2}{l}{ Funds that do not round to 5\% } & 21 & 45 & 27 & 7 \\
\hline
\end{tabular}

Explanation: All statistics are simple averages in \%. ${ }^{\text {a }}$ Sophisticated asset classes include real estate, commodities and loans. ${ }^{\mathrm{b}}$ Based on total investments (million euro).

\subsection{Home bias}

This section investigates in what degree pension funds diversify their investments geographically. International diversification can provide significant benefits by reducing risk for a given level of expected returns. However, not all investors exploit these diversification benefits to the full, as evidenced by their limited ownership of foreign shares. This phenomenon has been documented using both macro-economic data (e.g. French and Poterba, 1991) and firm-specific data (e.g. Kang and Stulz, 1997), as well as investor-specific data (e.g. Karllson and Norden, 2007). The main explanations point to explicit and implicit barriers to international investments. Other explanations include the use of domestic assets to hedge against unexpected changes in inflation and cognitive biases. However, these explanations have not been able to fully account for the lack of international diversification by domestic and foreign investors. Therefore, this phenomenon is known as the home-bias puzzle. 
Home bias usually refers to a preference by investors to hold domestic assets. Here we refer to more than proportional investment (of Dutch pension funds) in the euro area, as the data do not present greater detail. International diversification provides substantial risk-return benefits and hence home bias indicates a certain degree of shortsightedness that points to less sophistication. Table 7 shows that on average, large pension funds invest $30 \%$ of their assets within the euro area, while small pension funds' investments in the euro zone average $56 \%$ of assets. ${ }^{7}$ The home preference for assets from the euro area is at $48 \%$ much stronger in less sophisticated funds (which round to $5 \%$ ) than in sophisticated ones (36\%). This finding is consistent with a study by Karllson and Norden (2007), who report a higher likelihood of home-bias for less sophisticated investors with lower education levels and no previous experience with investments in risky assets. Remarkably though, the home bias is larger for sophisticated small and medium-sized funds compared to non-sophisticated funds of these size classes (which is unexpected), whereas it is much smaller for sophisticated large funds compared to non-sophisticated large funds, in line with 'theory'.

Table 7: Home bias of equity investments ${ }^{a}$ (2006:IV)

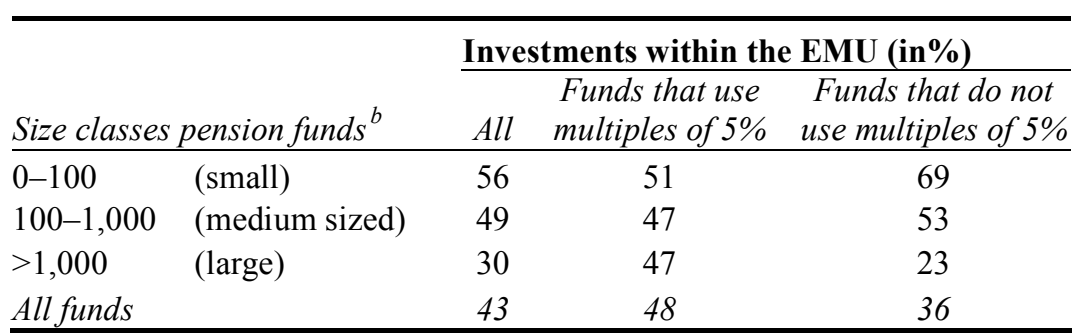

Explanation: All statistics are simple averages in \%. ${ }^{\mathrm{a}}$ Including exposure from derivatives; ${ }^{\mathrm{b}}$ Based on total investments (million euro).

We also observe home bias in all investments of pension funds with regard to the currency, where small and medium-sized funds hold around $85 \%$ of their assets in euros against $63 \%$ for large funds. This euro bias confirms the euro-area bias of Table 7. Incidentally, pension funds tend to hedge their currency risk with derivatives, reducing their net non-euro exposure to only $4 \%$ for small funds and $8 \%$ for large funds. Note that currency risk insurance does not wipe out the euro-area bias above, as the lack of international diversification remains.

\section{Sophistication and risk taking}

This section investigates a possible relationship between the measures of investment sophistication and risk taking. We hypothesize that pension funds with less investment expertise are generally

\footnotetext{
${ }^{7}$ The actual share of EMU assets in the world-wide total is just below 28\% (IMF Global Financial Stability report, April 2009).
} 
more risk-averse. Assuming that they are less knowledgeable about how to invest assets optimally, less sophisticated funds may deliberately choose a lower risk profile for their asset allocation. This strategy makes sense intuitively, as small funds may be less inclined to invest in risky assets since their limited sophistication and expertise makes them feel less comfortable with these risks.

Conversely, large funds are more likely to have significant in-house expertise and use sophisticated modeling techniques, which may make them less averse to risk taking. Sophisticated funds may suffer from overconfidence because they put too much trust in the theories and models they have developed (Griffin and Tversky, 1992). We note that the recent credit crisis shows that risk taking is not always a rewarding strategy. In the last decade, less sophisticated small funds have typically obtained higher investment returns than larger more sophisticated pension funds.

Figure 2 presents the average strategic equity and bond allocations over time for pension funds in different size categories. On average, large pension funds invest a greater share of their assets in equities and less in bonds, as also observed in Section 4.2. The graphs show that this latter effect is persistent over the entire sample period. Investing more in bonds, as small funds do, reduces the mismatch between the duration of assets and liabilities, and reduces the exposure to volatile equity

Figure 2: Strategic equity and bond allocations by pension fund size over time

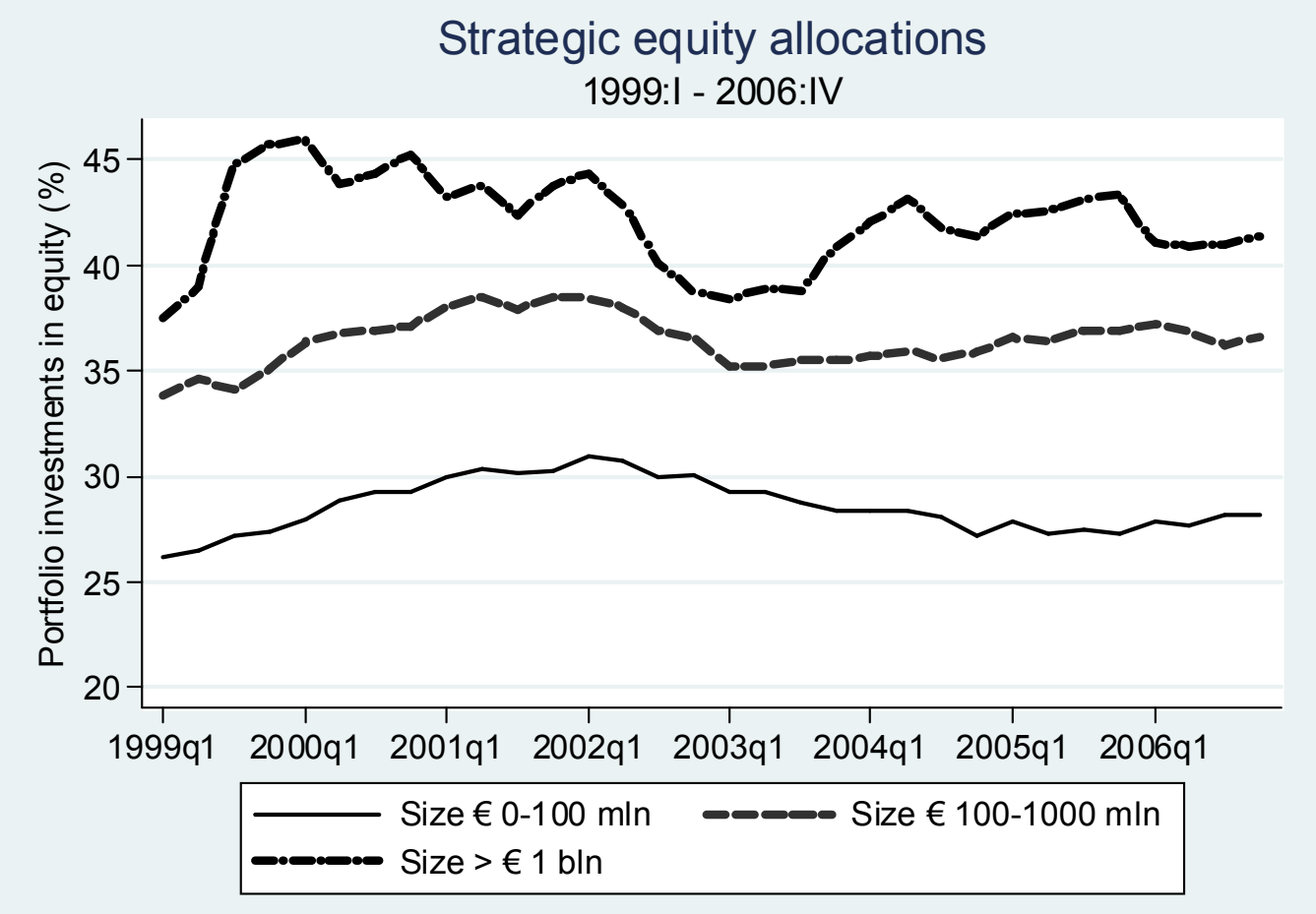




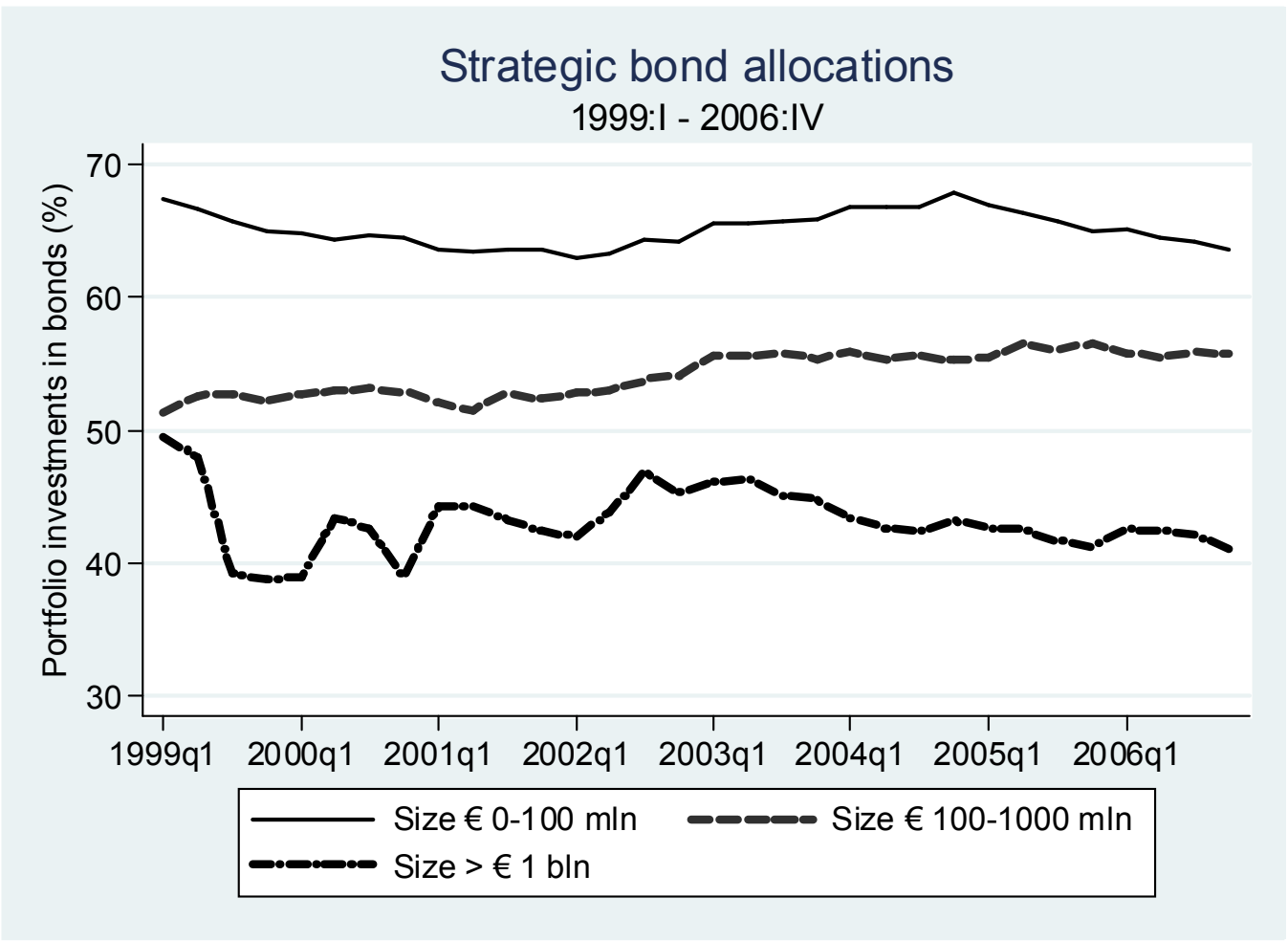

markets. ${ }^{8}$ Hence, the figures indicate that small and less sophisticated funds choose a lower risk exposure. Figure 2 further shows that strategic asset allocations vary significantly over time, reflecting the dynamic nature of investment policies. The strategic asset allocation is most volatile for large pension funds. They update their investment policy more frequently. Besides, the average of large funds is based on a lower number of pension funds, see Table 1.

To examine the relationship between measures of less sophistication and risk taking, we estimate the following equation:

$$
\begin{aligned}
\text { BondAllocation }_{i, t} & =\alpha+\beta \text { Heaping }_{i, t}+\gamma \text { Diversification }_{i, t}+\delta \text { HomeBias }_{i, t-1}+\varepsilon \text { Size }_{i, t-1} \\
& +\phi \text { Risk Preferences } \\
i, t-1 & +\varphi \text { Governance }_{i}+\eta_{i, t}
\end{aligned}
$$

\footnotetext{
${ }^{8}$ Nominal defined benefit pension liabilities are best resembled by nominal government bonds. Instead, defined benefit pension liabilities that are fully indexed to prices are best resembled by inflation linked bonds. In many Dutch defined benefit pension deals, indexation is contingent on the funding ratio of the pension fund. The market value of this contingent indexation can be derived using option pricing theory. In this case it might be optimal to have considerable equity exposure, see e.g. Broeders (2006).
} 
The dependent variable BondAllocation ${ }_{i, t}$ is the strategic bond allocation of pension fund $i(i=$ $1, \ldots, \mathrm{N})$ at quarter $t(t=1, \ldots, \mathrm{T})$. The explanatory variables Heaping and Diversification are dummy variables indicating less sophisticated asset allocation. Heaping equals one if the strategic equity and bond allocation are multiples of 5\% and zero otherwise. Diversification stands for sophisticated diversification and is defined as 'the strategic allocation to alternative sophisticated assets' minus 'the strategic investment in other simple assets', both as a percentage of total assets. HomeBias is the percentage of investments in the EMU.A positive estimate for $\beta$ and $\delta$ a negative estimate for $\gamma$ would indicate that pension funds with less developed strategies choose a lower risk profile for their portfolio by investing a higher share of their wealth in bonds.

The variable Size, measured as the log of total investments, is included to estimate the impact of scale on the risk profile of pension funds. This variable is included with a lag to avoid endogeneity problems, as positive returns on bond investments could automatically lead to an increase in both the strategic bond allocation and total investments during the same period (Bikker, Broeders and De Dreu., 2009). A negative estimate for $\delta_{1}$ would indicate that the investments of larger pension funds are riskier. Scale advantages should enable large pension funds to apply a better developed allocation policy and, therefore, this variable may also pick up some of the variation that not explained by the first two variables which are used as indicators for the sophistication of asset allocation (Heaping and Diversification).

RiskPreferences is a vector of three variables that control for risk preferences of participants and sponsors. The variable 'investments per participant' is included to control for the impact of higher average pension investments on risk preferences. A negative coefficient would indicate that participants with higher pension fund investments are less risk averse. The age variable 'percentage of pensioners' is included to control for the duration of liabilities. A positive coefficient for this variable would indicate that pension funds with a short investment horizon choose a lower risk profile (see Bikker et al., 2009). The variable 'funding ratio', calculated as total investments divided by discounted pension liabilities, is included because, from a sound risk management point, a higher buffer provides room to invest more in risky assets. ${ }^{9}$ This variable is included with a onequarter time lag to avoid endogeneity problems and since it may take some time before changes in the funding ratio affect a fund's strategic bond allocation.

\footnotetext{
${ }^{9}$ This is also according to the Dutch regulatory regime that requires that the probability of a funding ratio falling below $100 \%$ within one year must be less than $2.5 \%$. Next to that, pension funds should always have a minimum buffer of 5\%. This requires a higher buffer for risky portfolios and vice versa.
} 
Governance is a vector of three dummy variables that control for differences in the governance of pension funds. The variable 'Industry funds' equals one if the pension fund provides pension plans for employees in an industry and zero otherwise, whereas the variable 'Professional group funds' equals one if the pension fund provides a pension scheme to a specific professional group (e.g. medical profession, public notaries) and zero otherwise. Finally, the variable 'Defined contribution plan' equals one if a defined contribution pension scheme is offered, instead of a defined benefit plan.

Table 8: The strategic bond ratio and indicators of sophistication for various pension fund types (1999:1 - 2006:IV)

\begin{tabular}{lccc}
\hline & All pension funds & Company pension funds & Industry pension funds \\
\hline Heaping (gross rounding) & $0.032 * * *$ & $0.024 * * *$ & $0.074 * * *$ \\
Diversification in alternative & & & $-0.637 * * *$ \\
assets & $-0.288^{* * *}$ & $-0.187 * * *$ & $-0.015^{* * *}$ \\
Pension fund size (t-1) & $-0.026^{* * *}$ & $-0.028^{* * *}$ & $-0.810^{* * *}$ \\
Investments per participant (t-1) & $-0.030^{* * *}$ & $-0.028 * * *$ & $0.097 * *$ \\
Percentage pensioners & $-0.048^{* * *}$ & $-0.061 * * *$ & $-0.024 * * *$ \\
Funding ratio (t-1) & $-0.047 * * *$ & $-0.050 * * *$ & \\
Industry pension funds & $-0.030^{* * *}$ & & $-0.024 * *$ \\
Professional group pension funds & $0.057 * * *$ & $-0.050 * * *$ & $-0.062 * * *$ \\
Defined contribution plan & $-0.057 * * *$ & $-0.074 * * *$ & 2,119 \\
Intercept & $0.970 * * *$ & 11,143 & 206 \\
Number of observations & 13,517 & 304 & 0.45 \\
F-statistics & 460 & 0.16 & \\
R-squared, adjusted & 0.24 & & \\
\hline
\end{tabular}

Notes: Two and three asterisks indicate levels of confidence of $95 \%$ and $99 \%$, respectively.

Table 8 reports estimation results for Equation (1) except the home-bias variable, both for all funds and for company and industry funds separately. Inclusion of 'home bias' would reduce the number of observations from 13,517 to $1,737 .{ }^{10}$ All key variables enter with the expected signs and are significant at a $1 \%$ significance level in all three specifications (except the DC dummy for industry funds which is significant at a 5\% confidence level). The results provide strong evidence that small pension funds with less optimal allocation policies are more likely to choose low risk asset allocation strategies. Specifically, the heaping variable enters with a significant positive sign, showing that pension funds with less advanced asset allocation policies invest more in bonds. The

\footnotetext{
${ }^{10}$ We estimated also Equation (1) including 'home bias'. This variable enters significantly and with the expected sign (more home bias implies higher investments in bonds). The other two measures of (the lack of) sophistication show up with the expected sign, when they are significant, that is, for diversification (all variants) and heaping (industry funds). The results are available upon request.but have not been not reported since the number of observations for 'home bias' is relatively low.
} 
coefficient indicates that pension funds using multiples of $5 \%$ for their asset allocation invest, on average, 3.2 percentage points more in bonds (first column). The coefficient is even higher for Diversification, indicating that pension funds investing relatively more in alternative sophisticated assets and less in alternative simple assets, invest less in bonds. Finally, the size variable enters with a negative sign, indicating that large funds choose higher risk profiles by investing relatively less in bonds. An alternative size measure, that is, number of participants instead of total assets, leads to virtually identical estimation results. ${ }^{11}$

The two included risk preference variables carry their expected sign: a higher funding ratio and more investments per participant both imply a relatively lower allocation to bonds. A higher percentage of pensioners should result in a lower risk profile with relatively more bonds, but this is observed for industry funds only. In an alternative specification of model (1) we have used the equity ratio instead of the bond ratio as dependent variable (see Appendix). In this specification the percentage of pensioners consistently carries the expected sign, so that this effect appears to be sensitive to the precise choice of the dependent variable. ${ }^{12}$ Compared to company funds, industry funds hold relatively less in bonds while the reverse is true for professional group funds. The latter is explained in Bikker et al. (2009). Defined contribution plans, which have no nominal pension benefit target, tend to hold lower investments in bonds. The goodness of fit $\left(\mathrm{R}^{2}\right)$ in Table 8 is rather low, indicating that many other determinants of the bond ratio are not captured by model (1). This indicates a large impact on the strategic allocation of preferences, risk aversion and human judgment.

\section{Conclusions}

This paper develops three measures of the sophistication of pension funds' investment policy. Our results firstly show that most pension funds in the Netherlands select attractive numbers, particularly multiples of 5\%, for their allocation of both equities and bonds. This supports the observation that in the current practice, asset allocations do not follow directly from optimization of ALM models. Rather, the strategic allocation is determined by human judgment, given results from ALM studies. Coarse rounding is more frequent in smaller and medium-sized funds, indicating that sophistication is related to pension fund size. This is confirmed by the finding that smaller funds also invest less in alternative investments, other than equity and bonds. They invest particularly less in more sophisticated or complex other asset classes. This type of limited diversification is our

\footnotetext{
${ }^{11}$ The results are available upon request.

12 The bond and equity ratios are not (exactly) each other complement, as also other assets exists.
} 
second measure for (less) sophistication. Finally, smaller pension funds and medium-sized pension funds suffer more from home bias in their equity investment than larger pension funds. We find that these three measures are interrelated and correlated with pension fund size. These results suggest that the asset allocation policies of smaller funds are possibly less developed than they might be or, at the end, rely more on human judgment.

A striking finding is the huge variation of asset allocation across pension funds. We find that a major part of this variation is explained by the size of pension funds. Small funds tend to choose investment strategies with a lower risk (and lower expected return) profile and invest little in more complex alternative asset classes. The lower risk appetite of small funds may, in part, balance their limited sophistication with respect to the believed optimal asset allocation. However, even when controlling for size pension funds make significantly diverging choices. Theoretically these variations in asset-allocation could be explained by differences in risk preferences, fund characteristics and investment horizons of plan participants. However, these determinants explain only a relatively small part of the differences in bond and equity allocation. This outcome reflects widely varying views on the optimal investment mix. It seems likely that different risk-return assumptions of the various asset classes, expertise of pension fund investment managers and personal preferences of pension boards also play an important role. The analysis of this latter phenomenon is outside the scope of this paper, but is suggested as an interesting topic for future research.

The findings in this paper suggest that further consolidation of the Dutch pension sector, by mergers or further cooperation (e.g. in so called general pension institutions, which can provide pensions for companies or industries) may contribute to improved sophistication of the investment policy of pension funds. Such benefits of consolidation are in line with a previous study, in which we found that there is a negative correlation between the size of pension funds and administrative and investment costs per participant (Bikker and De Dreu, 2009). 


\section{References}

Agnew, Julie, 2002, Inefficient choices in 401(k) plans: Evidence from individual level data, Working Paper, College of William and Mary.

Agnew, Julie, Pierluigi Balduzzi, and Annika Sundén, 2003, Portfolio choice and trading in a large 401(k) plan, American Economic Review 93 (1), 193-215.

Bachi, Roberto, 1951, The tendency to round off age returns: measurement and correction, Bulletin of the International Statistical Institute 33, 195-221.

Banerjee, A., 1992, A simple model of herd behavior, Quarterly Journal of Economics 107, 797817.

Barber, B., and Odean, T., 2000. Trading is hazardous to your wealth: the common stock investment performance of individual investors. Journal of Finance 55, 773-806.

Baten, Joerg, Dorothee Crayen, and Brian A'Hearn, 2006, Quantifying quantitative literacy: Age heaping and the history of human capital, Working Paper 996, University Pompeu Fabra.

Benartzi, Shlomo, and Richard Thaler, 2001, Naïve diversification strategies in defined contribution saving plans, American Economic Review 91, 79-98.

Bikker, Jacob A., and Jan de Dreu, 2009, Operating costs of pension funds: the impact of scale, governance, and plan design, Journal of Pension Economics and Finance 8, 63-89.

Bikker, Jacob A., Dirk W.G.A. Broeders, and Jan de Dreu, 2009, Stock market performance and pension fund investment policy: rebalancing, free float, or market timing?, International Journal of Central Banking, forthcoming.

Bikker, Jacob A., Dirk W.G.A. Broeders, David Hollanders and Eduard Ponds, 2009, Age composition and asset allocation of Dutch pension funds, DNB Working Paper, forthcoming.

Broeders, Dirk W.G.A., 2006, The valuation of conditional pension liabilities and guarantees under sponsor vulnerability, DNB Working Paper no. 82, De Nederlandsche Bank, Amsterdam.

Budd, J. W., and T. Guinnane, 1991, Intentional age misreporting, age heaping and 1908 old age pensions act in Ireland, Population Studies 45 (3), 497-518.

Campbell, John Y., and Luis M. Viceira, 2002, Strategic asset allocation: Portfolio choices for long-term investors, Clarendon Lectures in Economics, Oxford University Press, 257 pages.

Canner, Niko, N. Gregory Mankiw, and David N. Weil, 1997, An asset allocation puzzle, American Economic Review 87, 181-191.

De Long, J. Bradford, Andrei Shleifer, Lawrence H. Summers and Robert J. Waldmann, 1990, Noise Trader Risk in Financial Markets, Journal of Political Economy 98 (4), 703-738. 
French, Kenneth R., and James M. Poterba, 1991, Investor diversification and international equity markets, American Economic Review 81 (2), 222-226.

Griffin, D., and Tversky, A., 1992, The weighing of evidence and the determinants of confidence, Cognitive Psychology 24, 411-435.

Hirshleifer, D. A., Subrahmanyam, and S. Titman, 1994, Security analysis and trading patterns when some investors receive information before others, Journal of Finance 49, 1665-1698.

Huberman, Gur, and Wei Jiang, 2006, Offering versus choice in 401(k) plans: Equity exposure and number of funds, Journal of Finance 61 (2), 763-801.

Kang, Jun-Koo, and Rene M. Stulz, 1997, Why is there a home bias? An analysis of foreign portfolio equity ownership in Japan, Journal of Financial Economics 46 (1), 3-28.

Karlsson, Anders and Lars L. Norden, 2007, Home Sweet Home: Home Bias and International Diversification among Individual Investors, Journal of Banking and Finance 31, 317-333.

Markowitz, Harry, 1952, Portfolio Selection, Journal of Finance 6, 77-91.

Myers, Robert J., An instance of reverse heaping of ages, Demography 13 (4), 577-580.

Odean, T., 1999. Do investors trade too much? American Economic Review 89, 1279-1298.

Shefrin, Hersh, and Meir Statman, 1997, Behavioral portfolio theory, The Journal of Financial and Quantitative Analysis 35 (2), 127-151.

Shleifer, Andrei, and Lawrence H. Summers, 1990, The noise trader approach to finance, Journal of Economic Perspectives 4, 19-33.

Sharpe, William F., 1964, Capital asset prices: A theory of market equilibrium under conditions of risk, Journal of Finance 19, 425-442.

Tobin, James, 1958, Liquidity preference as behaviour towards risk, Review of Economic Studies 25, 65-85. 


\section{APPENDIX THE EQUITY RATIO AND INDICATORS OF SOPHISTICATION}

Table 9 reports estimation results for an alternative of Equation (1), with the equity ratio instead of the bond ratio. All variables enter with a $1 \%$ significance level in all three specifications (except for sophisticated diversification in the company funds model). The results confirm that small pension funds with less developed allocation policies are less likely to choose more risky assets such as equity. Specifically, the heaping variable enters with a significant negative sign, showing that less advanced pension funds invest somewhat less in bonds. The coefficient indicates that pension funds that using multiples of $5 \%$ for their asset allocation invest, on average, 0.5 percentage points less in equity (first column). The coefficient is even higher for Diversification, indicating that pension funds that invest more in other sophisticated assets minus the strategic allocation in other simple assets (both as a percentage of total assets) invest more in equity. The total effect of the three measures of lack of sophistication is x percentage points. Finally, the size variable enters with a positive sign, indicating that large funds choose higher risk profiles by investing relatively more in equity.

The three risk preference variables have their expected sign: a higher funding ratio and more investments per participant both imply relatively higher equity investments, whereas relatively high numbers of pensioners, that is ageing, result in a lower equity ratio. Industry funds and professional group funds have less equity than company funds. Defined contribution plans, which have no nominal pension benefit target, tend to have higher equity ratios.

\section{Table 9: The strategic equity ratio and indicators of sophistication for various pension fund types (1999:1 - 2006:IV)}

\begin{tabular}{|c|c|c|c|}
\hline & All pension funds & Company pension funds & Industry pension funds \\
\hline Heaping (gross rounding) & $0.005 * * *$ & $0.008 * * *$ & $-0.017 * * *$ \\
\hline Diversification in alternative assets & $0.041 * * *$ & 0.006 & $0.283 * * *$ \\
\hline Pension fund size $(\mathrm{t}-1)$ & $0.027 * * *$ & $0.030 * * *$ & $0.009 * * *$ \\
\hline Investments per participant (t-1) & $0.053 * * *$ & $0.052 * * *$ & $1.317 * * *$ \\
\hline Percentage pensioners & $-0.073 * * *$ & $-0.067 * * *$ & $-0.198 * * *$ \\
\hline Funding ratio $(\mathrm{t}-1)$ & $0.052 * * *$ & $0.061 * * *$ & $0.015 * * *$ \\
\hline Industry pension funds & $-0.029 * * *$ & & \\
\hline Professional group pension funds & $-0.058 * * *$ & & \\
\hline Defined contribution plan & $0.026 * * *$ & $0.061 * * *$ & $0.015 * * *$ \\
\hline Intercept & $-0.042 * * *$ & $0.029 * * *$ & $0.090 * * *$ \\
\hline Number of observations & 13,517 & 11,143 & 2,119 \\
\hline F-statistics & 264 & 291 & 164 \\
\hline R-squared & 0.18 & 0.20 & 0.28 \\
\hline
\end{tabular}

Notes: Two and three asterisks indicate levels of confidence of $95 \%$ and $99 \%$, respectively. 